FACTA UNIVERSITATIS

Series: Visual Arts and Music Vol. 6, No 1, 2020, pp. 1 - 17

https://doi.org/10.22190/FUVAM2001001T

Original scientific paper

\title{
PLASTIC WASTE AS BOTH SOURCE OF INSPIRATION AND MEDIUM FOR CONTEMPORARY ARTISTS
}

\author{
UDC 73/76-053.5:069.9
}

\author{
Johannis Tsoumas \\ University of West Attica, Faculty of Applied Arts and Culture \\ Hellenic Open University, School of Humanities, Greece
}

\begin{abstract}
Amidst the technological, social, economic, and cultural developments of the past few decades, the notorious environmental problem seems to be exacerbated, overshadowing any glimmer of optimism about the future of planet Earth. This is largely attributed to the thoughtless production and use of plastic products, but mainly to their reckless management as waste. Oceans, rivers, lakes, and many terrestrial areas of the planet suffocate under the masses of synthetic objects that displace any form of life. The voices of despair are getting louder and louder all over the world, but governments in many countries pretend to hear nothing. Nevertheless, protest reactions coming from the world art and design community constitute an important visual, functional, as well as a sociopolitical movement with multiple goals.

This article does not simply aim at describing and analyzing the environmental problem through the aggravating presence of plastic waste. Its main purpose is to comment on and decode the works of selected artists from all over the world, works which are exclusively inspired and made of plastic trash. Overall, their work constitutes a form of artistic innovation and, at the same time, a form of severe protest and activism which aims at awakening the world aesthetic, and mainly environmental consciousness.
\end{abstract}

Key words: plastic waste, oceans, environmental pollution, recycling, works of art and design

Received November 11, 2019 / Accepted January 16, 2020

Corresponding author: Johannis Tsoumas

University of West Attica, Faculty of Applied Arts and Culture, Hellenic Open University, School of Humanities, Greece

E-mail: iannis33@hotmail.com

() 2020 by University of Niš, Serbia | Creative Commons Licence: CC BY-NC-ND 


\section{INTRODUCTION}

They have made their presence felt since the late nineteenth century, yet it was not until the early decades of the twentieth century that synthetic articles drastically invaded the American market and society, claiming one of the highest positions in the Pantheon of Immortals in the history of materiality.

The first experimental polymer products ${ }^{1}$ soon began to take various forms and uses. Objects made of celluloid, the first thermoplastic invented as early as the 1850s (Fenischell 1996, 17), bakelite, the miracle-material invented by the Belgian chemist Leo Henricus Arthur Baekeland in New York, in 1907 (Teegarden 2004, 59) and nylon, the revolutionary material originally used for fabrics and stockings (Wolfe 2008, 22) flooded the American market by the end of the interwar period. At the same time, but slowly, plastics began to dominate European markets, creating a new order of things in the cultural, social, and economic profile of the West.

During World War II, the industrial production of new plastics became directly associated with the success of the U.S. in the war. Many types of plastic materials were used for military equipment such as nylon parachutes, ropes and body armor, as well as plexiglass aircraft windows. However, both the production and variety of everyday household and personal use objects that mainly focused on the middle class and above, was still limited. It is easy then to understand that the pre-war market of plastic products was relatively smallscale, compared with the huge potential presented by the future purchasing power especially that of the working class-people, who, before the war regarded the world of the rich as a paradise impossible to be reached (Lintsen, Hollestelle and Hölsgens 2017, 20). According to my view this led to the identification of plastic materials with the notions of national victory and success, as since then plastics remained pioneering and promising products in the collective memory of the Americans of all classes. In the meantime, they managed to challenge traditional markets, taking the place of other original materials, such as steel in cars and machinery, glass and paper in package design and even wood in furniture, thus becoming more and more popular among the world consumer societies (Freinkel 2011, 4).

However, the unimpeachable optimism about them did not last for long as during the postwar decades they were proved to be profoundly guilty for a series of serious environmental crimes. Since the late 1960s plastics have started taking a rather inferior position in the collective memory of world consumers whose initial attraction to them would be gradually transformed to detestation, as they became symbols of superficiality and cheapness, but mainly of mass produced 'icons' of ecological threat and disaster.

So how did we get to the twenty-first century with such an accumulated problem that seems to threaten the global ecosystem, the stability and security of biodiversity, and the well-being of humans? What is the current situation on the aquatic landscape of the Earth and especially on the large oceans plagued by the plastic waste problem and what types of plastics are primarily responsible for this? And ultimately what is the position of the artists against this huge issue worldwide? How have their works tried, and finally managed, to transform this environmental curse into symbols and messages which aim at waking the cultural, social, and environmental awareness of mankind?

\footnotetext{
${ }^{1}$ Since then polymers started constituting the basis of the most important industrial goods of the twentieth century. Their rapid growth in production was primarily caused, beside financial, cultural, and social factors, by the gradual need of the world designers and markets to replace traditional materials.
} 


\section{The Plastics Waste Environmental Pollution and its ConseQuences: AN OVERVIEW}

The first serious samples of plastic's untimely behavior in nature and wildlife first appeared in the marine environment in the early 1960s. It was then that intense plastic debris in the Pacific American coast began to deeply concern Americans rendering them increasingly aware of the environmental pollution. In the late 1960s, the great fire that occurred in the Cuyahoga River in Ohio, as well as the oil slick that was observed in Santa Barbara, California and covered more than 30 square miles of ocean, raised their environmental concerns (Carlson 2019).

The next few decades before the year 2000 were particularly important for plastics' reputation worldwide and the rising of general anxiety about waste. During the 1970s, but mainly during the 1980s plastics finally confirmed their notoriety in the western markets consumer consciousness as their uncontrolled production automatically made them responsible for their mass disposability. By then people could finally understand that plastics would last forever in the environment harming it in various ways, through different forms, though.

In the late 1980s, and especially during the 1990s, the plastics industry, realizing the impending crisis on world markets, took major initiatives that led it to try to find ways that would not only detract it from the ever-expanding environmental contamination, but would make it significantly responsible for protecting the planet, to the destruction of which it had contributed to a huge extent. Thus, it started leading quite successfully an effective campaign encouraging local communities and municipalities worldwide to collect and process recyclable materials as part of their waste-management programs. Nevertheless, this initiative, however ambitious, seemed to be driven by failure as recycling soon made most plastics still end up in landfills or in the environment itself. Soon single-use plastic products, in spite of their usefulness, would increasingly flood the world markets and would fatally end up polluting the natural environment in several ways. Discarding plastics after use would then become one of the key reasons for the presence of so many synthetic products in the oceans. Items such as plastic drinking bottles, plastic lids, cigarette butts, personal care and cosmetic containers, food wrappers, plastic grocery bags, plastic cups, straws and stirrers, even buckets, chairs and tables entered the oceans and since they could not be fully biodegraded, they could affect fatally the environment (Wagner 2017, 120).

By the time, the most characteristic symbol of this issue would become the Great Pacific Garbage Patch ${ }^{2}$, a floating island of plastic garbage, including micro-plastics, as large as the size of Texas State, in the middle of the Pacific Ocean between America and Asia. Marine micro-plastics and nano-plastic particles that contaminate the oceans, but also the air and the land itself, can constitute a mere threat for any kind of life in the planet, mainly for the sea creatures ingesting them. Their presence in seafood can inevitably pose a threat to food safety and fatally affect humans who consume it (Johston 2016).

However, the most striking element of this little reference in the history of plastics is how fast their production accelerated in this millennium, despite their seriously negative impact on the environment and the well-being of humans and animals. The production of

\footnotetext{
${ }^{2}$ A floating landfill in the middle of the North Pacific Ocean, with hundreds of miles of plastic bottles, ropes, fishermen nets, cups and plastic bags. In spite of the fact that this part of the Ocean is known for the agglomeration of big to medium plastic objects, much of the debris found there is consisted of smaller parts of plastics or micro-plastics floating throughout water and just on its surface.
} 
plastic goods has increased in the last fifteen years almost as much as it had in the previous half century. The main drivers of this enormous production growth, however, are not the Western countries, but mainly the developing countries of South America, Africa and Asia which are also responsible for the mismanagement of plastics after their use (Zhang 2017).

Today single-use plastics constitute the biggest part of plastic waste. As most of them are petroleum based they are not biodegradable, and thus can easily break down into microplastics. Since they can release toxic chemicals they can also serve as magnets for other pollutants, including dioxins, metals and pesticides. We can see, therefore, that many times their 'cost of use' may be much higher than their production cost, as humans and the environment are the main recipients of their negative consequences (Knight 2012, 6).

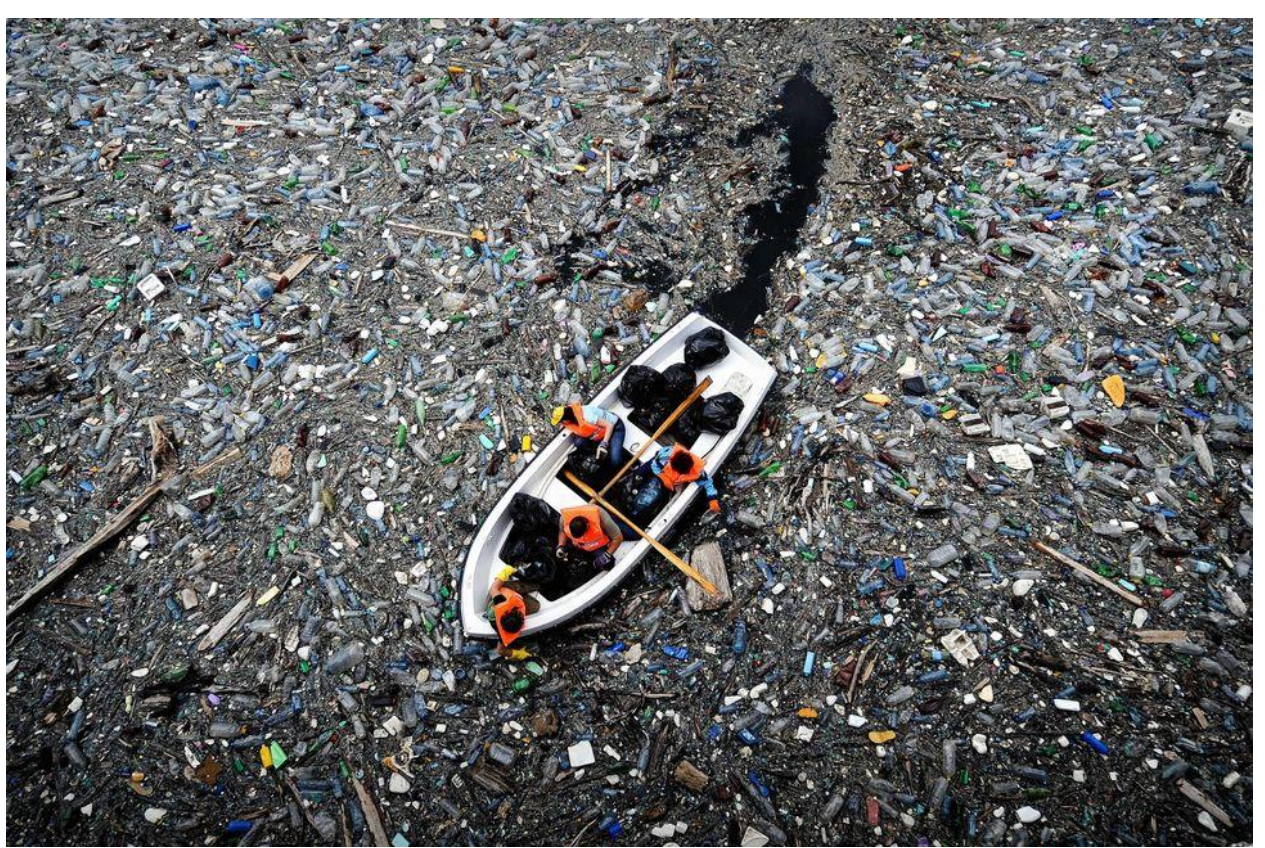

Fig. 1 Marine plastic debris constitutes one of the major causes of global environmental pollution. (C) Dimitar Dilkoff via Getty Images.

Packaging waste, followed by waste derived from other sources of consumption such as vehicles and electronics, is considered the most consumed type of single-use plastics. It is estimated that it accounts for almost half of the plastic litter in the whole world (Tsoumas 2019, 83-84). However, plastics bags and containers are themselves a special category of plastics waste. In spite of the fact that plastic bags can be taken as the cult objects of the current convenience culture, at the same time they constitute an omnipresent consumer objects on the planet, as their yearly production can be numbered in trillions. It has been noticed that only in America more than one hundred billion plastic bags are thrown away after they have fulfilled their purpose in the transportation of goods from big supermarkets, groceries or drug stores to home or elsewhere (Mieszkowski 2007). Recent research has suggested that, because of their components such as petroleum, natural gas and several 
toxic colorants they can be extremely destructive for both the environment and urban life. Thrown away in masses they can block or pollute waterways by clogging up water or sewer pipes and even drains turning them into ideal places for insects and pests breeding. In many cases plastic transparent bags are found to be taken as food by hundreds of marine species, among which there are the already endangered sea turtles and many sea mammals, but also sea birds which can easily mistake them for jelly fish. Their lethal composition can block their airways and digestive systems and therefore can constitute the basic cause for their immature death (Earth Policy Institute 2018).

\section{ART AS A FORM OF PROTEST}

Fyodor Mikhailovich Dostoyevsky's well-known expression Beauty will save the world in his book 'The Idiot' may nowadays be replaced by the expression Art will save the world, as in our time, more than ever in the history of humanity, art and, in particular, the power of human creativity and inventiveness are important answers to the alarming problem of environmental pollution in which the role of plastic waste is of paramount importance. Art is a means of recording, annotating and perhaps regulating the political, social, and cultural conditions of each historical period. It is now noted to having taken a leading role in the case of the very recent phenomenon of the environmental issue in history. Now that the world societies are beginning to be severely affected by the overwhelming problem of plastic waste and, at the same time, become more aware of the concept of sustainability on several fields of their living environment, art through the concepts of recycling and reusing cheap, damaged and environmentally hazardous plastic items is once again a pioneer in a cultural and social awakening campaign.

It should be noted, however, that the relationship of synthetic materials to art, in general, has not been a recently established issue. The first hesitant contact with the twentieth century art would begin with the small production of the first acrylic paints for artists in the late 1940s. Soon this new medium would become particularly popular, since it gave even more freedom of expression to the artists of the time. This would enhance the emergence of new art movements in the US and Europe in the 1950s and 1960s, such as the American Abstract Expressionism and Pop Art. ${ }^{3}$ High range artists such as Morris Louis, Jules Olitski, Mark Rothko and later Andy Warhol and Helen Frankenthaler would be among the first to discover the top qualities of acrylic paints which, like no other media of that time, would be extraordinarily versatile in terms of glossiness, thickness and texture (Mustalish 2004). However, none of the leading artists of that time could even have thought that plastics, which had already become cult idols for the Western consumer societies, would in themselves be not only sources of inspiration, but also a kind of art media and a form of social protest in the following decades, especially in the beginning of the new millennium.

By late twentieth century many fields of the visual arts began to show enormous interest in the creeping catastrophe caused by plastic trash, and therefore their response to such a great challenge to the world cultural and environmental heritage was immediate. Yet, it is widely believed that it is only in the last fifteen years that artists, designers and even craftsmen worldwide managed to produce important works, all of which constitute a great

${ }^{3}$ It is not accidental the fact that both movements coincided with the great production and consumption boom initially occurred in the US and later in Europe mainly during the 1950s where synthetic products were almost idolized. 
environmental message to all directions. Areas brutally affected by the threat of plastic waste danger, such as the U.S., several parts of Asia, Oceania, and Europe seem to send S.O.S. messages all over the world, not in plastic bottles thrown into the ocean, but through works of art that stand out for their amazing conceptual, aesthetic and ecological sensitivity. Art, in all its forms, begins to take the initiative of resisting the overwhelming indifference of the governments of many countries of the world against this threatening phenomenon, hoping for its gradual repression by having as sole weapons the power of culture, notion and public awareness.

Multicolored, glossy or blurred by the ocean salt and the strong sun light, in tiny, small or large sizes, transparent and gelatinous like jellyfish and shrimps, translucent like oyster pearls and opaque like floating pumices, the washed ashore plastic garbage items constitute today a unique source of inspiration and media for contemporary artists. Environmental sculpture, installations, design works, photography and other forms of visual arts claim the 'glow' of the most characteristic waste of modern culture and are being upgraded both in the world of art, and in the collective consumer consciousness.

\section{DifFERENT FormS OF PlASTIC TRASH ART}

One of the most important conceptual artists of the new generation in the U.S., considered as one of the first in the world to discover the importance of the conflicting relationship between nature and global consumerism culture, is Pamela Longobardi who started to 'build' her own ecological ideology for art as early as 2006. Regarding herself as both an artist and an activist, she initially focused on the immediate removal of plastic waste from the coasts and beaches of America, mainly Hawaii, but also from other parts of the globe such as the Mediterranean Sea and the Gulf of Mexico, with a view to their complete cleaning. Her next step was to proceed to the transformation of these hitherto environmentally damaging materials into impressive, massive pieces of art.

This important initiative began with the implementation of the famous Drifters Project, an action program for the creation of art with plastic waste, through a serious research methodology, that focused intensively on social participation. The program was attended not only by the local authorities of each region it was applied in, but also by its citizens, regardless of age. It was also supported by the operation of specialized workshops, as well as by the relevant media of each place, which strove by all means to raise the public awareness for the need to rehabilitate coastal areas by finding new and viable alternatives to the use of plastic products, especially single-use ones. The activism seen in Longobardi's work was the beginning of a relationship of great importance among ordinary people, researchers, artists and scientists and aimed at making the seriousness of the marine debris pollution problem understood by everybody $\left(\mathrm{O}^{\prime}\right.$ Halloran \& Fournier, 2019, 17). Finally, the process of collecting plastic objects, sorting and subsequently transforming them into large-scale sculptures, installations, as well as inventive photography works were the ultimate goal of this ambitious project which still has numerous supporters all over the world. 


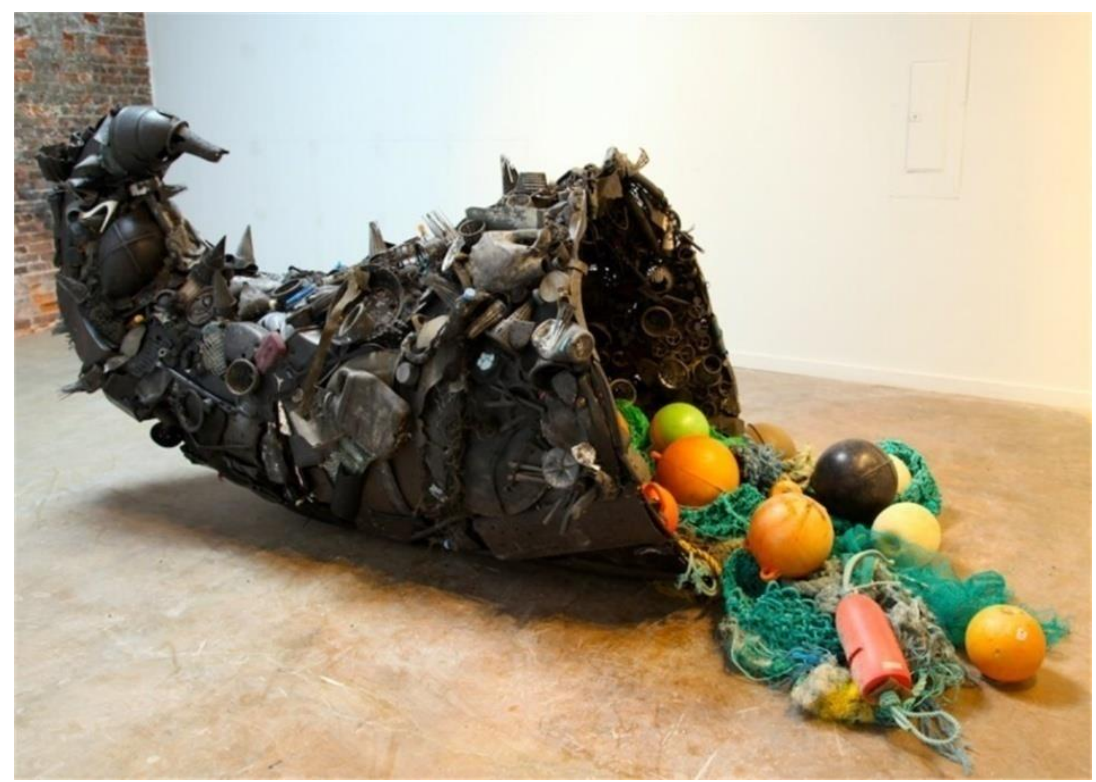

Fig. 2 Pamela Longobardi: Bounty, Pilfered, 2014. Fishing nets, floats and plastic parts on metal armature. (c) Chris Arend, Anchorage Museum.

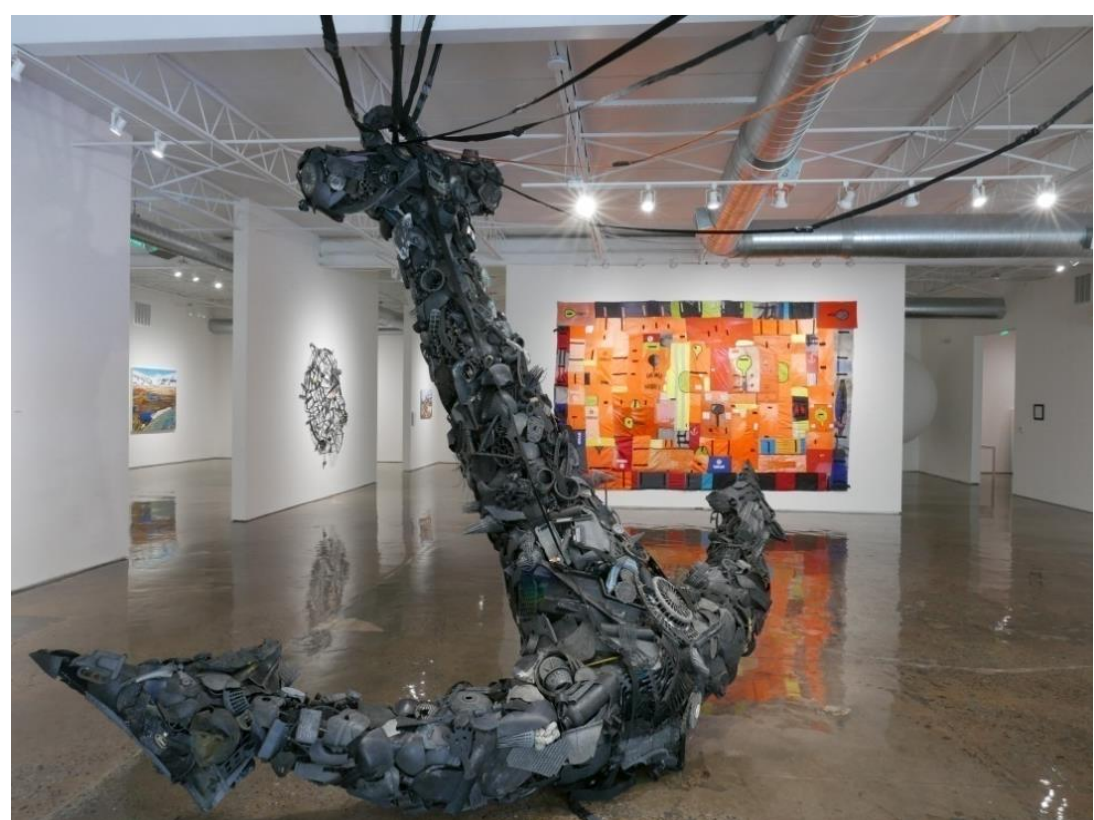

Fig. 3 Pamela Longobardi: Anchor (our albatross), 2017. Urban and ocean plastic waste from Hawaii, Atlanta and Greece. () Hathaway Contemporary Gallery. 
The biggest and most interesting part of her work has started being presented since 2014 at the famous 'Hathaway Contemporary Gallery" in Atlanta, in solo exhibitions including, inter alia, her famous works Bounty, Pilfered (2014) (Fig. 2) and Anchor (our albatross) (201) (Fig. 3). These two large-scale sculptures that dominated the exhibition seemed to create a sense of anti-culture on the current common perception of consumerism. Both are made mainly of black plastic objects, but also of others painted black, as they aimed to inform the visitors about the devastating effects that 'black gold', the basic material for plastics, has on environment.

The main symbolism of the huge Anchor tied to the ceiling of the room with plastic straps is the imperative need of humanity to stop the eternal journey of marine plastic garbage in the oceans. It also signifies concepts such as hope, steadfastness, safety and the effort to keep plastic waste agglomerated in particular areas so as to be easily controlled. In the case of the Bounty, Pilfered sculpture, the ironic and perhaps heartbreaking use of the mythical symbol of Amalthea's horn that instead of richness and abundance of goods scatters garbage and waste, is a punch to the stomach of all who have not yet grasped the magnitude of the environmental issue.

A similar outreach campaign, addressed mainly to the inhabitants of the Italian peninsula through art, and in particular large installations, has been launched by the Italian architect, artist and president of the great transmedia project 'Garbage Patch State', Maria Cristina Finucci since 2013.

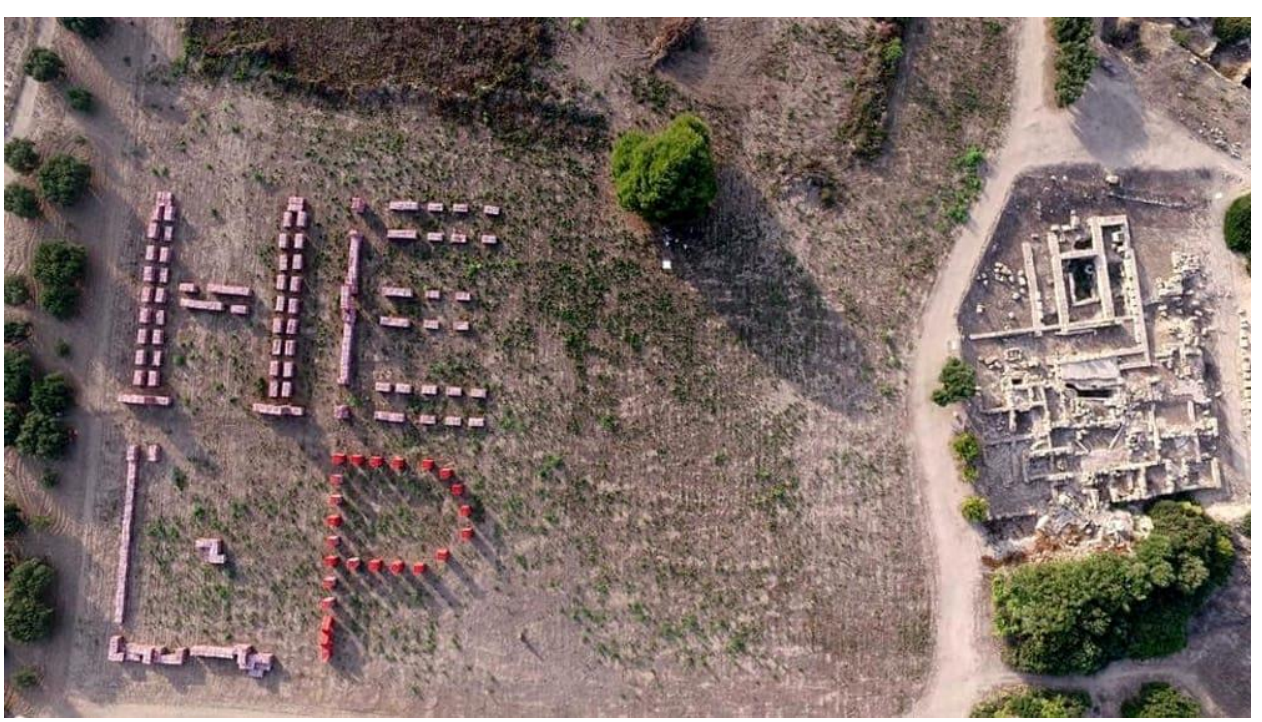

Fig. 4 Maria Cristina Finucci: Help the Ocean installation, Mozia island, 2016. (C) Wikimedia Commons.

\footnotetext{
${ }^{4}$ A relatively new but excitingly rising and much promising new gallery in Atlanta, U.S.. Its main purpose is to promote well-known, but mainly young and talented artists with innovative work characterized by the use of new materials and technologies, in many fields of the visual arts.
} 
Carried by currents and winds, marine plastic debris has created a gigantic, new 'deadly ecosystem' in the oceanic environment and especially in the sea around Italy. Keeping always in mind that art would be the only means that could have a direct impact on consumer consciousness, Finucci embarked on a glorious quest, in the framework of her great project, in order to face this disaster, applying just her art. Her primary, rough ideas were soon transformed into an ambitious installation, titled Help the Ocean, (The Age of Plastic) (Fig. 4). It consisted of more than five million brightly colored plastic bottle tops set in specific metal letter forms so as to spell out the word 'Help', manually assembled and weighed more than two tons in total. The monumental installation was impressively big so that it could be seen almost from everywhere, and symbolized humanity's cry of despair to face the disastrous environmental issue of the sea pollution. There was no coincidence that it was first presented on the island of Mozia, off Sicily, in 2016, as both its coastline and Sicily's greater region are literally plagued by the polluting power of plastic debris (Valeri 2016, 37).

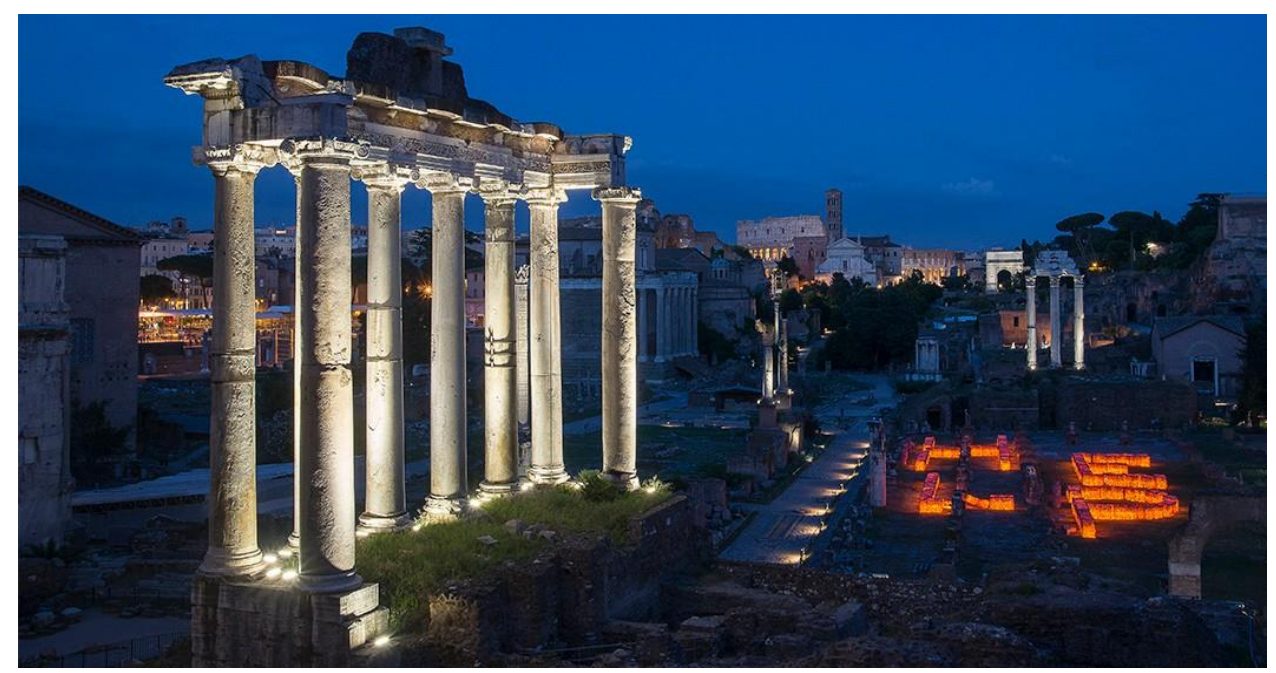

Fig. 5 Maria Cristina Finucci: Help the Ocean lit installation. Ancient Roman Forum, Rome, 2018. ( ) Luca Regoli.

The environmental sculpture, which could be lit at night, was placed next to the archeological site of the island constituting a direct challenge for the spectators who would have the opportunity to visit, at the same time, two totally different areas of world art and culture history: the ancient Phoenician archeological site which was next to it and, in direct contrast, the invasive remnants of modern post-capitalist culture, turned into art. Having managed to combine contemporary art with archeology and rural landscape, but mainly with the visitors' need to get answers to their ecological questions, Finucci installed the same work in the Ancient Roman Forum, Rome, in 2018, by projecting the same parallel meanings ${ }^{5}$ (Fig. 5).

${ }^{5}$ The particular project was supported by Fondazione Bracco, an Italian Foundation for the promotion of arts, culture and science with serious and effective activity. 
The messages of her work, similar to the work of most of the artists involved in the transformation of plastic waste into art in open spaces, are also strongly political in that they touch on the very serious problem of environmental pollution in a spectacularly public way, thus revealing the long-standing indifference of the world governments on this issue.

The overall work of the Cameroon-born, world-renowned artist, Pascale Marthine Tayou, is a constant questioning of the social and political situation in his country during post-colonial times, as well as an apt commentary on many important current issues such as human evolution, globalization, the greenhouse effect, the Aids neo-culture in Africa and environmental pollution (Wright 2009). He considers himself a curious traveler and explorer, since he loves to collect cultural and social experiences from around the world, and his work after 2000 seems to focus much more on the concepts of the ephemeral and the temporal. Collecting disposable items such as public transport tickets, batteries, packaging wraps, plastic razors and bags he tries to create a unique form of art by incorporating them in his projects in a magical way through his multiple talents as an artist, since besides being a skillful sculptor, he is also a painter, a performer, an installator and a video artist (Jouano 2000, 115).

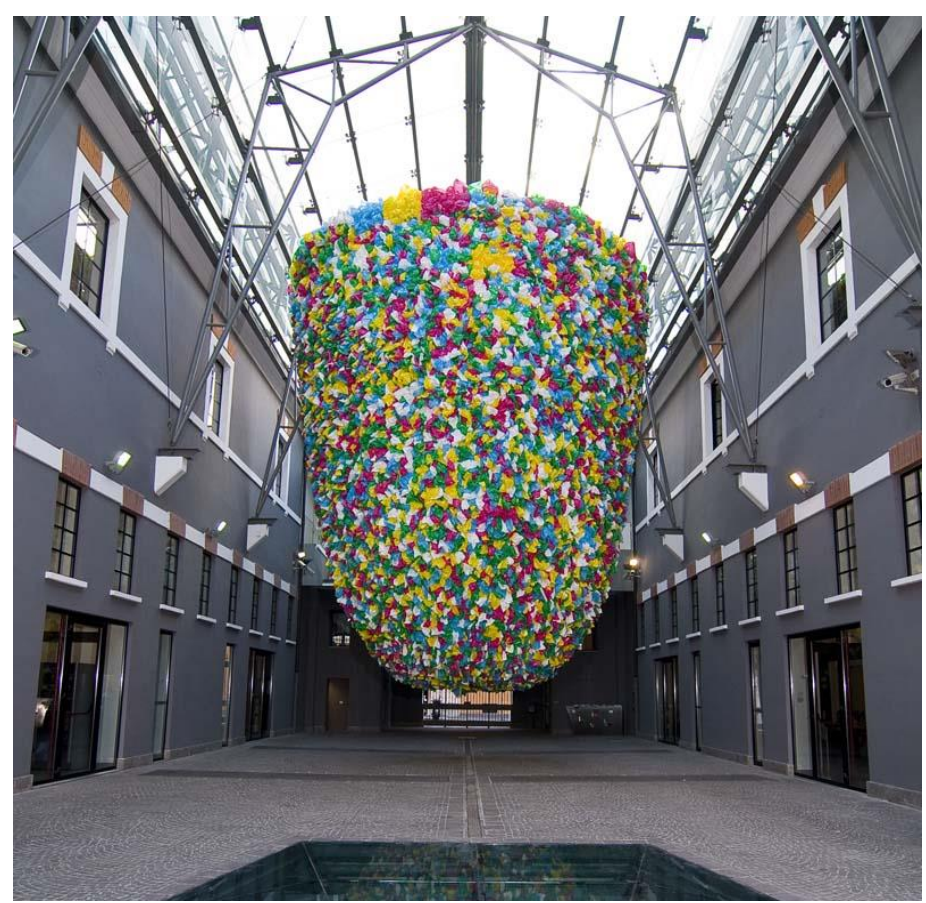

Fig. 6 Pascale Marthine Tayou, Plastic Bags installation, 2013. (c) Giorgio Benni / Queensland Art Gallery.

His great attraction to plastic objects has led him to vigorously experiment with materials that, in his own view, reflected the notions of the moral, aesthetic, and cultural depreciation of today's societies and that is why his works bear so many strong symbolisms and allegories. Plastic bags, the main symbol of mass production and consumerism 
subculture and, as it has been stated before, one of the most environmentally hazardous types of single-use plastics, constituted, not accidentally, the basic material of some of his major works. Tayou believed that, at the same time, they represent the concept of wandering, but also those of randomness and homelessness, as after they are discarded, they never stop wandering in the world seas, lakes and rivers, therefore he conceived the idea of an enormous bullet-shaped installation made of plastic bags, which he finally managed to accomplish in 2013. The ten meters-high work appropriately titled Plastic Bags sculpture (Fig. 6) dominates any space in which it is exhibited, not only because of its big volume, but also of its influence on visitors' psychology. At first sight, the striking range of colorful plastic bags creates a rather appealing effect to them evoking feelings of happiness, fulfillment, and joy. However, the crumpled material of the objects which betrays their plastic origin and their negative effects on the environment, soon reverses their first positive impression, creating feelings of bewilderment and reflection.

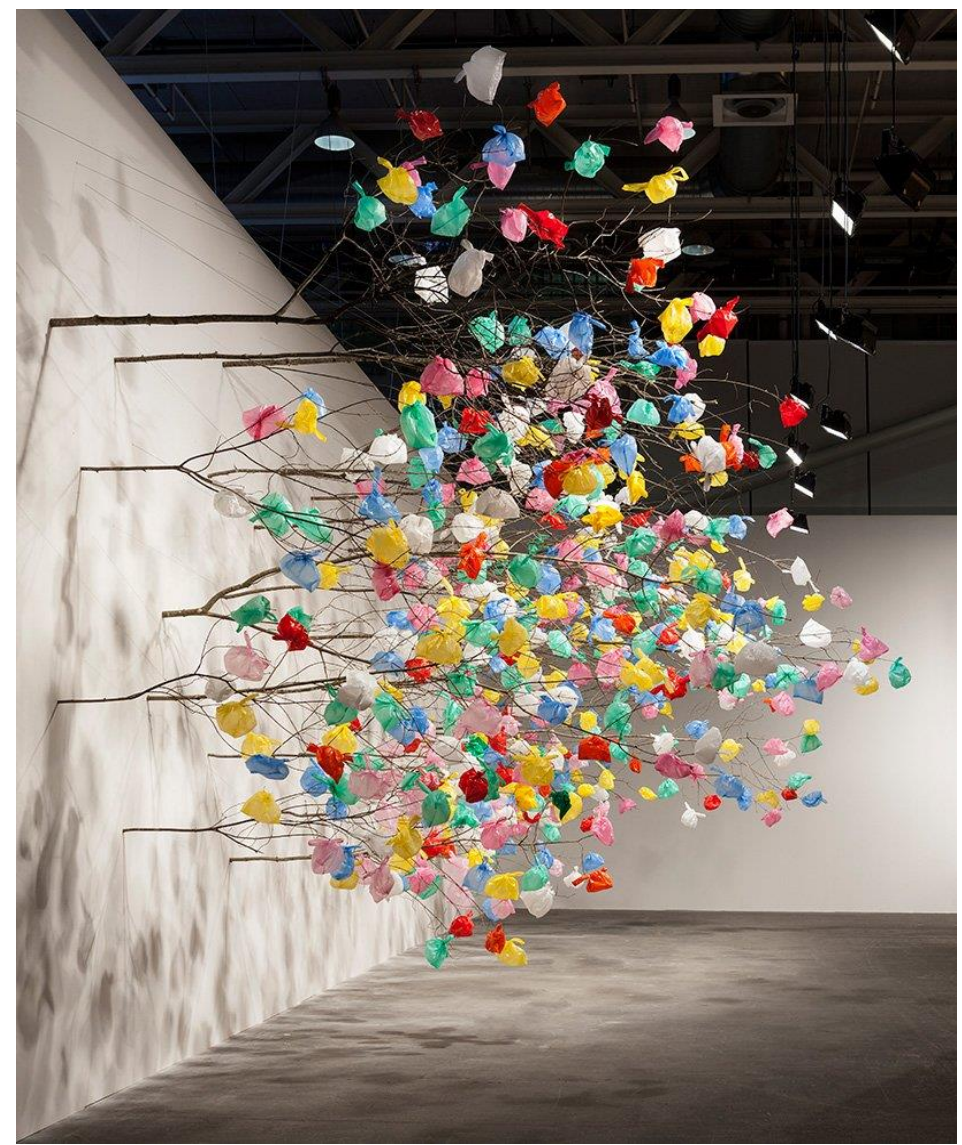

Fig. 7 Pascale Marthine Tayou, Plastic Tree, 2015. (c) Andrea Rossetti / Galleria Continua.

With the same artistic approach he created shortly thereafter another symbolic work originally exhibited in the framework of Art Basel Unlimited, Basel, with Galleria Continua 
in 2015. The Plastic Tree or else Tree Branches installation (Fig. 7) which expanded on the whole length of an enormous white wall creating an extraordinary forest atmosphere, made a positive impression for the important connotations it bore. The various-sized tree branches which grew horizontally from the white wall had on their edges colorful plastic bags rather than leaves, breaking purposely any nature laws and rules. Plastic here served as a unique art medium which not only revealed Tayou's deep exploring this particular material and its potential use, but also symbolized the detrimental effects of plastic trash and therefore consumerism on nature itself.

Over the past decade the field of photography became richer with the imaginative work of the British international award-winning photographer Mandy Barker who managed to create her own style, through her great artistic research the central theme of which was the marine plastic debris. Due to her individual style which is mainly attributed to her work thematography, many of her images have been published in major magazines and newspapers around the world including The Explorer's Journal, The National Geographic Magazine, Financial Times, The British Journal of Photography, The Guardian and others. As with previous artists, here plastic waste is also used as a central theme in order to express the artist's concern for the environmental disaster and also the potential effect it can have in climatic change (Fotografiska Museum (2019). Her idea to experience the ocean plastic trash phenomenon in person was proved to be catalytic for her decision to make art with it.

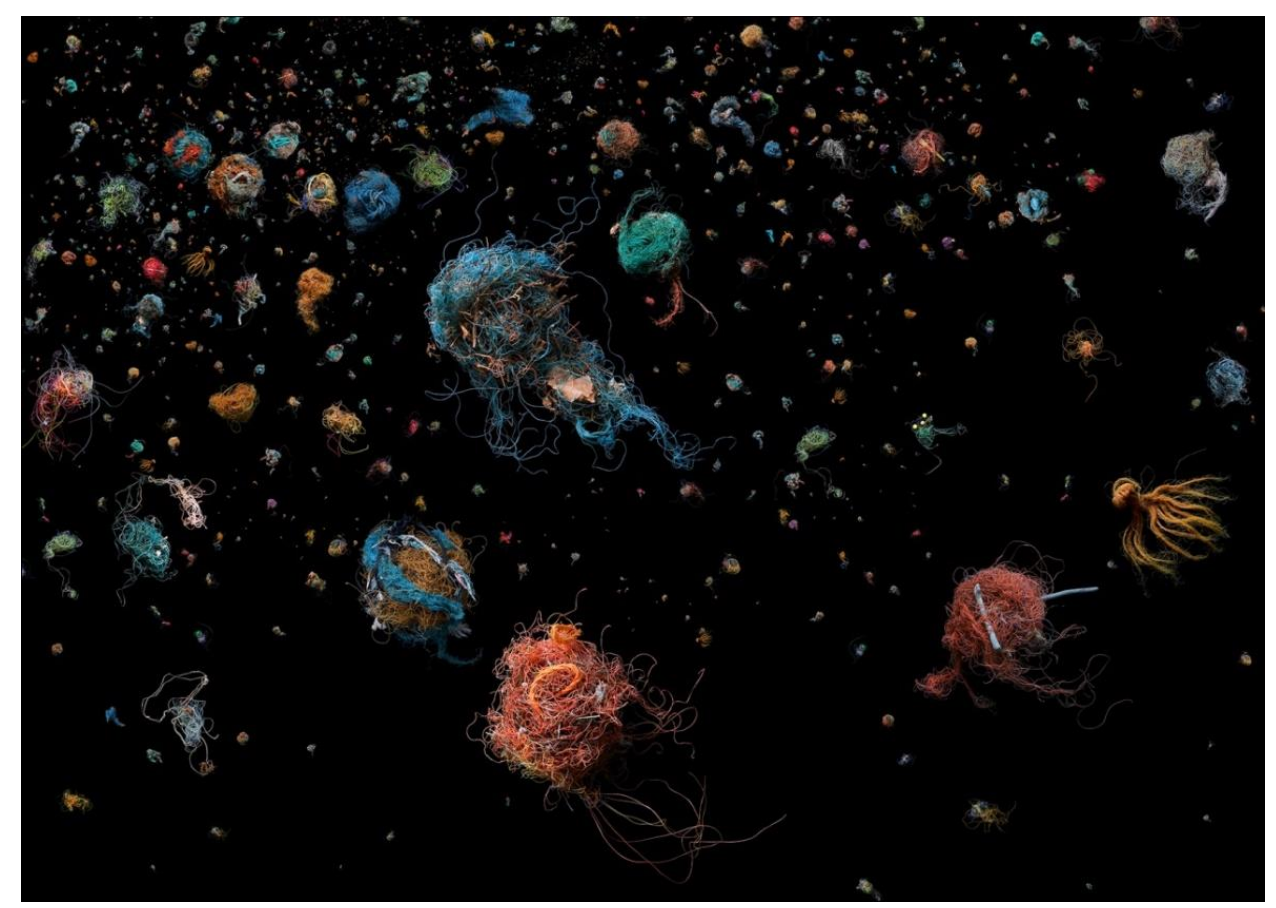

Fig. 8 Mandy Barker: from the project Soup, photograph titled Bird Nests, 2011. (C) Mandy Barker. 
After having followed several scientists on their exploring trips around the globe spanning from the West coast of America to Japan, and having recorded the plastic waste 'voyage' from the South Asian coasts to the British Isles, Barker managed to create a project that would focus on the human contribution to the huge amount of marine debris around the world. The meticulously collected pieces of plastics of various sizes, colors and styles, usually set on dark backgrounds, and they constitute a new idea of composition which leads to a totally different kind of photography and, at the same time, suggest a new way of seeing both art and environment.

In her 2011work titled Soup (Fig. 8), part of the broader project Our Plastic Ocean, her images do have an impressively dual interpretation. They can remind to the viewers of sea animals, such as jelly fish and turtles, but also sea weeds and corals floating peacefully in dark sea water. On the other hand, they do reveal their real identity: their plastic waste origin which is both cruel and horrifying. Coffee-cups and lids, fishing nets, pieces of string, parts of bottles and toys, buttons and cotton-buds mixed together either forming a particular shape or in random, suspended in a dark nowhere, do stimulate spectators' minds and emotions with severely contradicting messages, which however can be impressively effective mainly as environmental pollution alert agents.

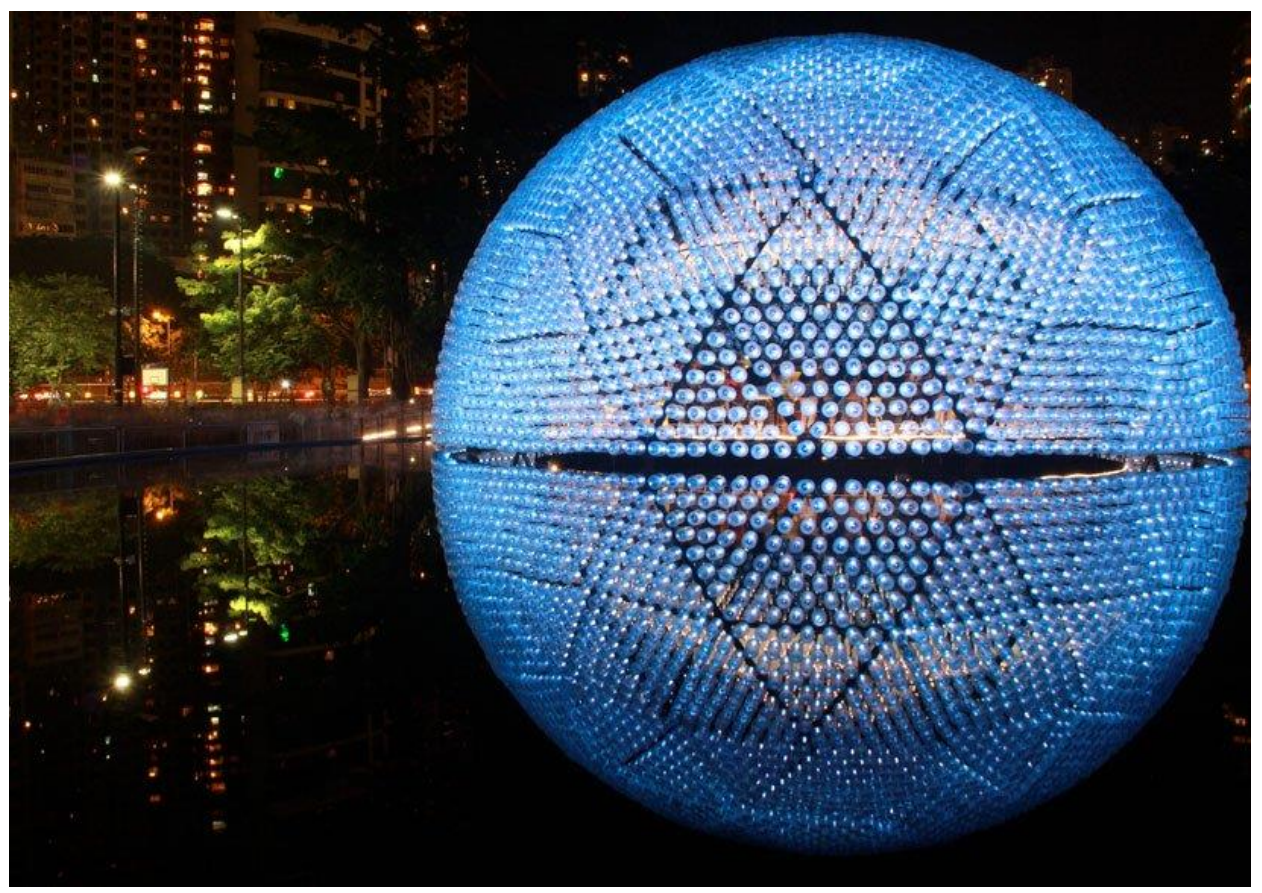

Fig. 9 Daydreamers Design Co. Rising Moon project, exterior view. Hong Kong, 2013. (c) Charles Chun Wai Lai.

Another environmental sculpture reeling between fine arts and design or environmental pavilion as it was called, was constructed and installed in Victoria Park, Hong Kong, as part of the mid-autumn Lantern Wonderland Design Festival and Competition in 2013. 
According to the century-old Chinese tradition, the celebration of the Mid-Autumn Festival was associated both with the harvest time and with the gathering of people with their families and friends once a year under the Autumn full moon which was considered the symbol of good crop and reunion (Nguyen 2003, 93). Daydreamers' Design ${ }^{6}$ long-awaited project titled Rising Moon (Fig. 9). It was just a temporary construction, that managed to win the first prize of the competition as it was considered an original idea both culturally and ethically and it sensitively touched on Chinese traditions and at the same time promoted strongly the ecological problem of the area that was no other than the pollution of the South China Sea by plastic debris (Miao 2016, 59). The art installation in the form of an almost complete hemisphere, 20 meters in diameter by 10 meters in height, was made of thousands recycled, five-gallon water plastic bottles, sprayed in the tones of blue, green and red, which were carefully attached on a prefabricated metal structure composed of several triangleshaped pieces. The bottles contained numerous LED lights which, when lit, gave to the bottles an ethereal, glowing effect which not only reminded of the traditional Chinese paper lanterns, but also reflected the vibrant Hong Kong city night life and culture.

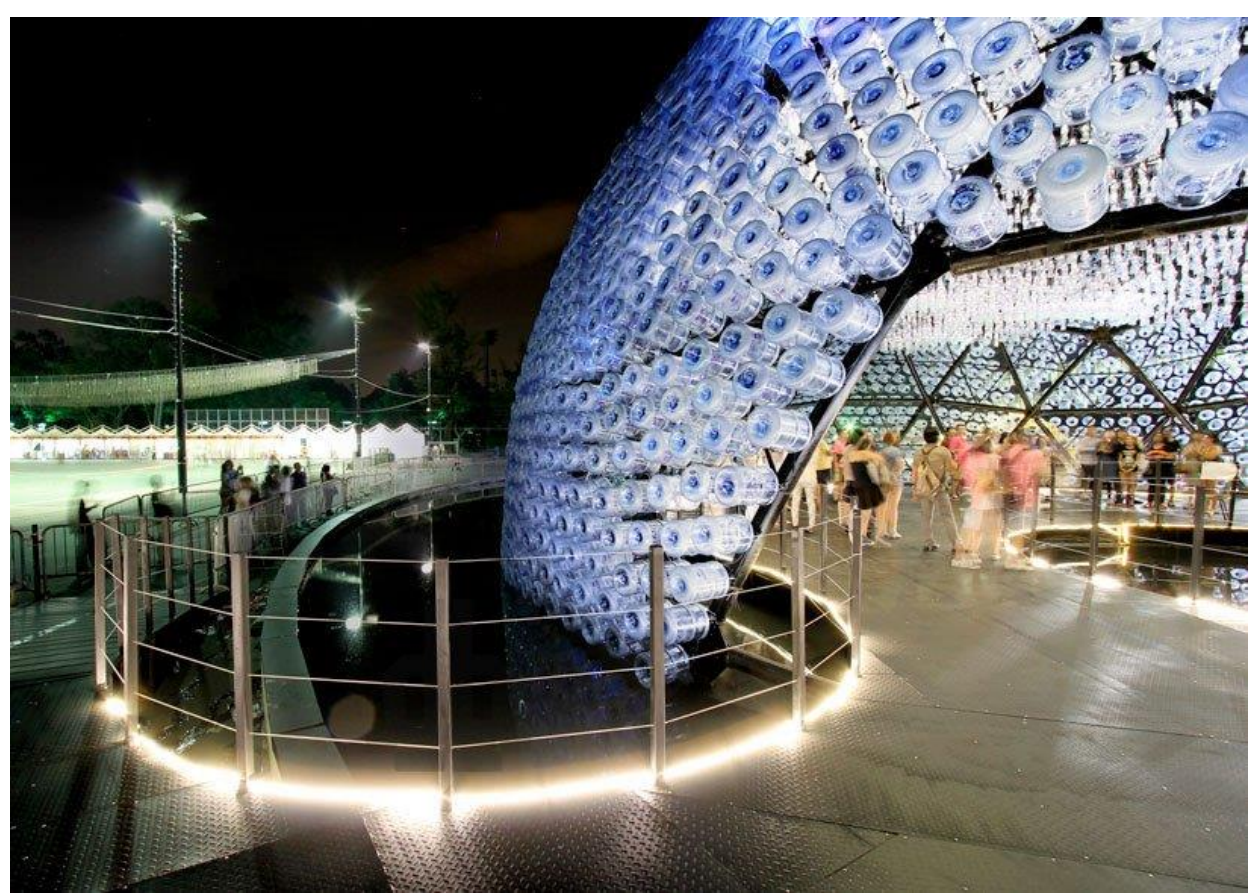

Fig. 10 Rising Moon, interior partial view. () Vincent Chi Hin Kar.

The interior of that giant Synthetic Moon was also covered with more than two thousand and three hundred bottles hanging from the ceiling in a wavy formation which due to its glass-like effect gave the impression of a huge lit ecological candelabrum. An

\footnotetext{
${ }^{6}$ Daydreamers Design Co. was founded in Hong Kong and is an art, design and architecture group working on particular projects both locally and globally. The company aims to pursue individual research methodologies, create new, sophisticated design ideas and collaborate with renownd artists and designers from all over the world.
} 
opening at the top of the installation allowed moonlight to pass inside, highlighting the illumination of the transparent interior almost metaphysically. The marvelous visual impact of the sculpture was supported with the appropriate sound effects both externally and internally making it even more startling.

There was also a wooden pathway which would cut through the structure enabling visitors to enter the Rising Moon installation, and experience its lucent magic and high symbolisms (Fig. 10). Its carefully chosen position on the top of a swimming-pool, enhanced the bold reflections of the colored, illuminated bottles on the surface of the water, symbolizing the different phases of the moon. Additionally, this allowed it to have an almost perfect hemi-sphere shape visually. This was successfully reflected on the pool water as its other half giving to the viewers the illusion of a floating luminous sphere. After it was deconstructed, it was completely recycled, promoting once more Hong Kong as the city of world sustainability and eco-friendliness.

\section{CONCLUSION}

'So, more than a substance, plastic is the very idea of its infinite transformation; as its everyday name indicates, it is ubiquity made visible. And it is this, in fact which makes it a miraculous substance: a miracle is always a sudden transformation of nature. Plastic remains impregnated throughout with this wonder: it is less a thing than the trace of a movement' (Barthes 1973, 104).

In the above words of Roland Barthes, one of the greatest thinkers of the twentieth century, we can detect some grains of a prophecy. After forty-six years it turned out from this statement that plastics, despite having become a real threat to the environment and humans, emerged again as the protagonists of a new order of things and thus climbed successfully both in the hierarchy of art and in the general consumer cultural consciousness. Through their pervasive utilitarian and cultural values for the consumer societies of the twentieth and the twenty first century, as well as through their rugged and painful course in the oceans, rivers, lakes, forests, valleys, fields and landfills of our planet, plastics as waste began to be those post-industrial objects that had to preserve their myth, even through other forms of creation or use. It was their own destructive power that made them be an inspiration, but also unexplored and valuable media for many enlightened and talented artists who managed to create with them a different kind of art, full of alarming messages for the global environment protection, especially for the aquifer.

Nowadays the haunting, but at the same time, encouraging recycled plastic waste art is on the rise in most areas of the planet where the environmental problem is intense.

Artists such as Von Wong and Joshua Goh from Singapore, Daniel Webb from U.K., Veronika Richterova from the Czech Republic, Franklin Gavua from Ghana, Tuula Närhinen from Finland, Mbongeni Buthelezi from South Africa, Diana Cohen from the U.S. and many others, are important representatives of an informal new artistic movement, with a strongly ideological, social and political character, that finds followers everywhere. This dual activist and artistic campaign aims at conveying messages of optimism and hope to address the problem, through the stimulation of consumer awareness and the projection of new inventive art ideas, techniques, methods and finally complete works, globally. New and old art galleries, open public spaces, many cultural institutions, museums, even highly respected archaeological sites have accepted without 
any hesitation this new initiative that opens new avenues for the definition of selfexpression through art, but also for the 'building' of personal and collective responsibility in such crucial environmental issues.

\section{REFERENCES}

Barthes, R., (1973), Mythologies. Glasgow: Paladin Books, Glasgow.

Carlson, C., (2019), 'The 1969 Santa Barbara oil spill: An environmental 'shot heard around the world', [Online]. Available: https://eu.vcstar.com/story/news/special-reports/outdoors/2019/01/24/santa-barbaraoil-spill-1969-environmental-movement-california-offshore-drilling-epa/2486352002/ [Accessed on 28 October 2019]

Earth Policy Institute (2018), 'Plastic Bags Fact Sheet'. [Online]. Available: http://www.earth-policy.org/ press_room/C68/plastic_bags_fact_sheet [Accessed on 20 October 2018].

Fenichell, S. (1996), Plastic: The Making of a Synthetic Century. New York: Harper Collins.

Fotografiska Museum (2019) 'Mandy Barker: Sea of Artifacts'. [Online]. Available: https://www.fotografiska. com/sto/en/news/mandy-barker-sea-of-artifacts/ [Accessed on 2 November 2019].

Freinkel, S., (2011), Plastics: A Toxic Love Story. New York: Henry Holt.

Johston, I., (2016), 'Plastic should be considered toxic once it gets into the environment, MPs told'. Independent. [Online]. Available: https://www.independent.co.uk/environment/plastic-microplasticmicrobeads-pollution-toxic-environment-house-of-commons-environmental-audit-a7011256.html [Accessed on 29 October 2019].

Jouano, E., (2000), 'Pascale Marthine Tayou'. Nka: Journal of Contemporary African Art. 2000 (11-12)

Knight, G., (2012), Hot Topics: Plastic Pollution. London: Capstone Global Library Ltd.

Lintsen, H. W., Hollestelle M. J., Hölsgens H. N. M., (2017), The plastics revolution: how the Netherlands became global player in plastics. Eindhoven: Foundation for the History of Technology.

Miao, S., (2016), 'Exciting New Horizons Ahead'. Perspective: Inspiring Architecture and Design. 7.

Mieszkowski, K., (2007), 'Plastic bags are killing us' [Online]. Available: https://www.salon.com/2007/08/ 10/plastic_bags/ [Accessed on 31 October 2019].

Mustalish, R., (2004), 'Modern Materials: Plastics.' In Heilbrunn Timeline of Art History. New York: The Metropolitan Museum of Art. [Online]. Available: http://www.metmuseum.org/toah/hd/mome/ hd mome.htm [Accessed on 31 October 2019].

Nguyen, V. H., (2003), 'The Mid-Autumn Festival, Yesterday and Today', in Vietnam: Journeys of Body, Mind, and Spirit. Los Angeles: University of California Press.

O' Halloran, C. \& Fournier, G., (2019), 'Turning Ocean Garbage into Advocacy Art', Global Journalist, Missouri School of Journalism.

Teegarden, D. M., (2004), Polymer Chemistry: Introduction to an Indispensable Science. Arlington VA: NSTA Press.

Tsoumas, J., (2019), 'Designing Single-Use Plastic Products: Far from the Earthly Paradise'. American Scientific Research Journal for Engineering, Technology, and Sciences (ASRJETS). 52, (1)

Valleri, M., (2016), 'L' installazione all' isola di Mozia: Help, il grido del Mediterraneo'. Tempi 1 (3).

Wagner, T. P., (2017), 'Reducing single-use plastic shopping bags in the USA', Journal of Waste Management, 70 .

Wolfe, A. J., (2008), 'Nylon: A Revolution in Textiles'. Chemical Heritage Magazine, 26 (3).

Wright, K., (2009), 'Pascale Marthine Tayou'. [Online]. Available: https://www.artinamericamagazine. com/news-features/magazines/pascale-marthine-tayou/ [Accessed on 1 November 2019].

Zhang, S., (2017), 'Half of All Plastic That Has Ever Existed Was Made in the Past 13 Years'. [Online]. Available: https://www.theatlantic.com/science/archive/2017/07/plastic-age/533955/ [Accessed on 29 October 2019]. 


\section{PLASTIČNI OTPAD KAO IZVOR INSPIRACIJE I MEDIJ SAVREMENIH UMETNIKA}

Usred tehnološkog, društvenog, ekonomskog i kulturnog razvoja tokom poslednjih nekoliko decenija, čini se da se ozloglašeni problem zagađenja životne sredine pogoršava, zasenjujući svaki delić optimizma u pogledu budućnosti planete Zemlje. To je u velikoj meri posledica nepromišljenje proizvodnje $i$ upotrebe plastičnih proizvoda, ali prvenstveno nemarnog upravljanja otpadom. Okeani, reke, jezera i mnoga koopnena područja naše planete guše se pod masom sintetičkih objekata koji utiču na sve oblike života. Glasovi očaja postaju sve glasniji i glasniji širom sveta, ali vlade mnogih država pretvaraju se da ništa ne čuju. Ipak, protestne reakcije koje dolaze iz sveta umetnosti $i$ dizajna predstavljaju važan vizuelni, funkcionalni $i$ društvenopolitički pokret sa višestrukim ciljevima.

Ovaj članak nema za cilj samo da opiše i analizira problem zagađenja životne sredine kroz ugrožavajuće prisustvo plastičnog otpada. Njegova glavna svrha je komentisanje $i$ dekodiranje radova odabranih umetnika iz celog sveta, dela koja su isključivo inspirisana $i$ napravljena od plastičnog otpada. Sve u svemu, njihov rad predstavlja oblik umetničke inovacije $i$ istovremeno oblik oštrog protesta $i$ aktivizma koji imaju za cilj da probude svetsku estetsku $i$ prvenstveno ekološku svest.

Ključne reči: plastični otpad, okeani, zagađenje životne sredine, reciklaža, umetnička dela, dizajn 